\title{
Preventing Policy Capture and Promoting the Public Interest in Policy Making: Lessons for Botswana ${ }^{1}$
}

\author{
Abiodun M.T. Omotoye \\ Associate Researcher \\ Botswana Institute for Development Policy Analysis \\ Governance and Administration Unit \\ omotoyem@bidpa.bw
}

\section{Summary:}

African governments continue to face a myriad of political, social and economic challenges. Since the 1990s, a number of reforms, aimed at improving the manner in which governments can become more efficient, responsive, accountable and transparent, have been introduced across the continent with mixed results. Botswana has consistently been lauded for its commitment towards upholding the rule of law and observing principles of good governance. However, corruption remains a reality and threatens the country's status as Africa's 'shining example'. This brief paper is an output of a conference presentation delivered by the author at the Botswana Centre for Public Integrity (BCPI) Integrity Week (12 - 14 September 2018) held in Gaborone, Botswana. The paper conceptualizes policy capture and discusses how public interest in policy making can be enhanced in Botswana. The paper is structured as follows. Section 1 provides definitions of policy, policy capture, and public interest. Section 2 attempts to address the question: "How do we Prevent Policy Capture?", while Section 3 addresses "How do we Promote the Public Interest in Policy Making". Section 4 provides an overview of Botswana's efforts to control corruption and promote public interest in the policy making process.

\section{DEFINING POLICY, POLICY CAPTURE, AND PUBLIC INTEREST}

\subsection{Policy}

Policy, specifically, a public policy can simply be defined as a statement of intent. It specifies the basic principles to be pursued in attaining specific goals by interpreting the values of society (De Coning, 2006). For example, in Botswana's context, we can make reference to a number

\footnotetext{
${ }^{1}$ This is a revised version of the presentation delivered at the BCPI Integrity Week in Gaborone, Botswana, 12 14 September 2018
} 
of national policies that have been developed by the Government of Botswana, such as the National Health Policy, Revised National Policy on Education, National Disability Policy, etc.

\subsection{Policy Capture}

Transparency International (2014) describes state or policy capture as one of the most pervasive forms of corruption, where private firms or even individuals (within or outside a country) employ corrupt methods to influence and shape a country's policy and legal environment to their own interests.

\subsection{Public Interest}

Who is the public and what are its interests? Simply stated, the "public" includes the widest scope of society, individuals and groups, affected directly or indirectly by the activities of the state. The fundamental challenge facing the state has always been to balance the competing interests or values of these groups (Figure 1).

Figure 1: Group Model of Policy Making and Implementation: Phase I

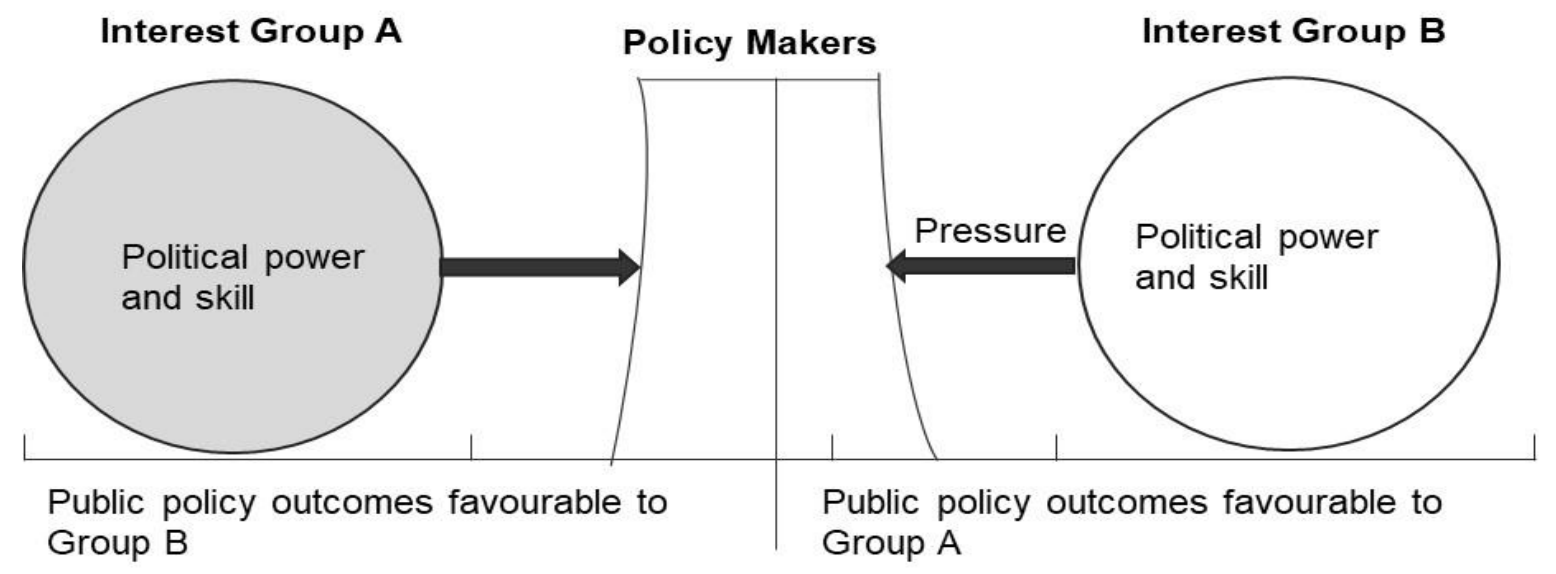

Source: Henry (1992)

Figure 1 illustrates the ideal scenario as it is desirable for all actors. However, the reality is that the level of political power, skill and influence of a certain group can outweigh the attributes of another group, which results in an imbalance (Figure 2). 
Figure 2:Group Model of Policy Making and Implementation: Phase II

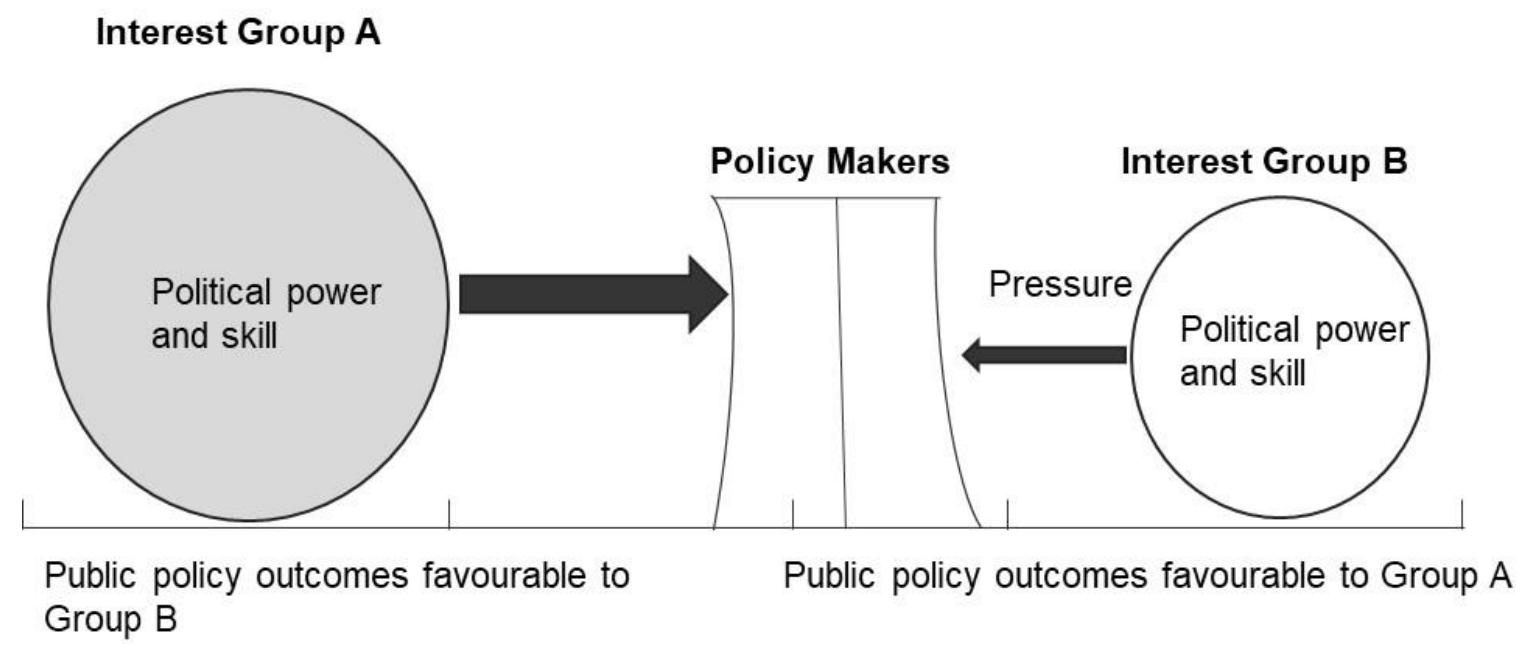

Source: Henry (1992)

The main risk with policy capture is that decisions no longer take into consideration the public interest, but instead favour a specific group. That is, laws, policies and regulations are designed to benefit a certain interest group, often to the detriment of a smaller group or society in general. As Figure 2 illustrates, Interest Group A wields greater power and skill than Interest Group B. Therefore, it is in a better position to influence the decisions of policy makers.

\section{HOW DO WE PREVENT POLICY CAPTURE?}

No country is immune to policy capture. In all political systems, whether democratic or authoritarian, groups compete for influence over the state to have an impact on the choice and design of laws, rules and regulations in order to shape these rules of the game to their own advantage (Hellman and Kaufmann, 2001). The fact that corruption occurs in secrecy, particularly grand or political corruption, it is critical that political leaders are committed to promoting a culture of transparency and accountability in the public service. Arguably, corruption does not thrive where information on processes, procedures and issues of national interest are freely open to the public. Furthermore, it is important that citizens are given an opportunity to voice their concerns about government performance, and that such concerns are taken as equally serious by government.

Policy capture is not a new phenomenon nor is it observed in developing countries alone. Table 1 presents country examples of policy capture in countries, both developed and developing. 
Table 1: Country Examples of State Capture

\begin{tabular}{|c|c|c|}
\hline Country & Description & Source \\
\hline Singapore & $\begin{array}{l}\text { - Financial services sector exercises strong } \\
\text { influence over law-making } \\
\text { - Since 1990s, financial markets \& banking } \\
\text { sectors have been liberalised } \\
\text { - Former ministers \& civil servants are } \\
\text { members of boards of banks } \\
\text { "Conflict of interest does not exist" }\end{array}$ & $\begin{array}{l}\text { Tax Justice Network (2013) [in } \\
\text { Transparency International 2014] }\end{array}$ \\
\hline $\begin{array}{l}\text { United States of } \\
\text { America }\end{array}$ & $\begin{array}{l}\text { Corporations are extremely powerful and } \\
\text { have used lobbying \& campaign financing to } \\
\text { exercise control over the rules governing } \\
\text { their operations }\end{array}$ & Transparency International (2014) \\
\hline Europe & $\begin{array}{l}\text { Cloudy lobbying practices \& politicians' } \\
\text { dependence on private donations for } \\
\text { financing of election campaigns } \\
\text { Business corps often have direct access to } \\
\text { politicians in many European countries }\end{array}$ & $\begin{array}{l}\text { Alter EU [in Transparency } \\
\text { International 2014] }\end{array}$ \\
\hline South Africa & $\begin{array}{l}\text { Business family (Gupta) close ties with } \\
\text { former President J. Zuma, several ministers } \\
\text { and ANC top officials } \\
\text { Guptas used ties to influence decision- } \\
\text { making e.g. appointment of ministers \& } \\
\text { abuse of state resources }\end{array}$ & Meirotti and Masterson (2018) \\
\hline Zimbabwe & $\begin{array}{l}\text { - State-party conflation ensured the electoral } \\
\text { dominance of one party } \\
\text { - State resources reserved for Mugabe family }\end{array}$ & Meirotti and Masterson (2018) \\
\hline
\end{tabular}

Evidently, cases of policy capture occur at the highest political echelons. Unlike petty corruption (often associated with junior level employees), policy or state capture is characterised by blurred relations between senior government officials and an influential private sector elite. Not only does it occur amongst individuals, but it can also occur at a political party level (for example through secret funding campaigns). This undermines the rule of law, perpetuates socio-economic inequality, and weakens democratic institutions and processes.

\section{HOW DO WE PROMOTE THE PUBLIC INTEREST IN POLICY MAKING?}

According to the Australian Public Service Commission (Undated), public officials have an over-arching obligation to act in the public interest. They must perform their official functions 
and duties, and exercise any discretionary powers in ways that promote the public interest. The myth that policies are defined and shaped only by policy makers has been busted, as evidenced by increasing involvement of non-state actors in the policy formulation process, especially in well-established democracies. However, policy making may still be considered by some as an elitist exercise.

Consequently, members of the public may feel disillusioned and develop apathy towards this critical process. This may also be brought about by the perception that governments are not entirely responsive to the real needs of the public (i.e. state goals are misplaced/not prioritised). Despite the fact that public officials and institutions of government exist to serve the interests of the public, it remains important the public itself plays an active role in issues of public interest such as policy making, implementation, as well as monitoring the successes and failures of policies. Public participation in policy making is an opportunity for citizens, CSOs and other interested parties to influence the development of policies and laws that affect them. Conversely, the importance of public officials engaging the public in these processes cannot be underestimated and is recognised as a key part of good governance practices and development in general.

\section{BOTSWANA'S EFFORTS TO CONTROL CORRUPTION AND PROMOTE PUBLIC INTEREST IN POLICY MAKING: AN OVERVIEW}

\subsection{Controlling Corruption}

Prior to the release of Transparency International's 2018 Corruption Perception Index results, Botswana was considered the least corrupt country in Africa. However, the 2018 results revealed that Seychelles had surpassed Botswana as the least corrupt in Africa (see Figure 3). Botswana's drop in the CPI ranking is not necessarily attributed to an increase in perceived levels of corruption. In fact, Botswana's world rank improved from $36^{\text {th }}$ in 2017 to $34^{\text {th }}$ in 2018 . However, it is apparent that countries, like the Seychelles, have made significant strides in controlling corruption, whereas Botswana has been consistent with its efforts. 
Figure 3: Corruption Perception Index World Rank (Botswana and Seychelles) ${ }^{2}$

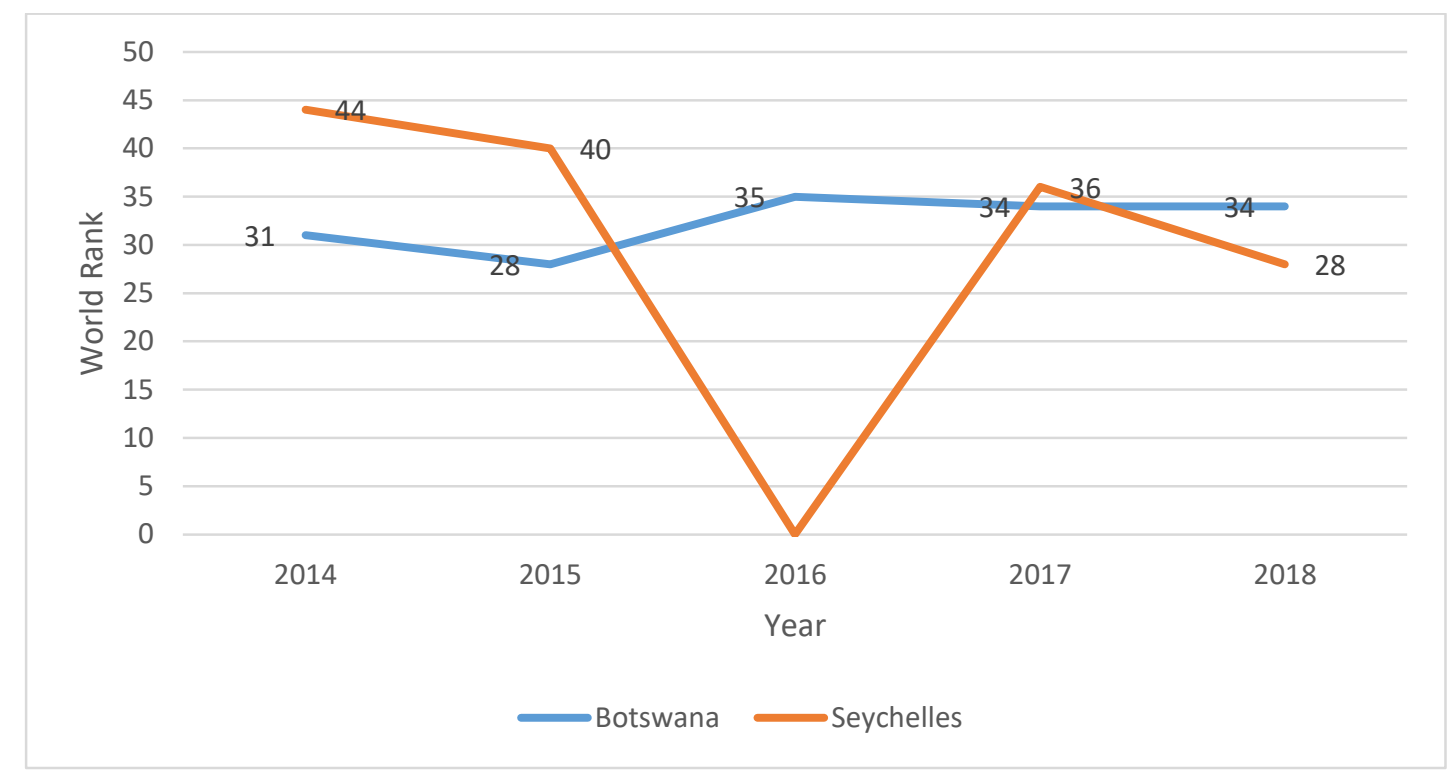

The Government of Botswana recognises that a collective effort is required to combat corruption and address other socio-economic challenges. Civil society organisations are called to be partners of the state, but also act as watchdogs. Despite progress in some areas of anticorruption reform (e.g. amendment of Corruption and Economic Crime Act, promulgation of Whistleblowing Act, establishment of anti-corruption committees across government departments) several challenges still hinder effective anti-corruption efforts in Botswana. This includes: (a) absence of a Right to or Freedom of Information Act, (b) Declaration of Assets and Liabilities Act, (3) regulations on political party funding, (4) and an efficient e-government system that improves service delivery and increases public participation.

\subsection{Promoting Public Interest in Policy Making}

The Government of Botswana acknowledges that citizen participation is vital to the successful development and implementation of national policies. National Development Plan 11 states that promoting citizen participation entails involving all citizens in open discussions on the development and improvement of policies and strategies. The traditional Kgotla system (a consultative forum between public officials and the community, used to discuss issues of importance to the community in question) has been hailed for its bottom-up approach, but questions of its effectiveness have been raised because of weak attendance by members of the community. Other examples include the: National Business Conference, and High Level

\footnotetext{
${ }^{2}$ Data unavailable for Seychelles in 2016.
} 
Consultative Conference, but it is critical to ask whether these platforms give ordinary Batswana an opportunity to participate meaningfully? Specifically, what barriers (e.g. logistical, financial, informational) do such fora pose to ordinary citizens in determining their ability to access and contribute to national discourse that affects them directly or indirectly?

\section{REFERENCES:}

Australian Public Service Commission. (Undated). Available from:

https://www.psc.nsw.gov.au/employmentportal/ethics-conduct/behaving-ethically/behavingethically-guide/section-4/4-1-acting-in-the-public-interest. Accessed: 10 September 2018.

De Coning, C. (2006). The nature and role of public policy. Improving Public Policy, from theory to practice, Cloete, F., Wissink, H. and De Coning, C (eds.). Pretoria: Van Schaik Publishers.

Hellman, J. and Kaufmann. (2001). Confronting the Challenge of State Capture in Transition Economies. Finance and Development, 38(3). Available from:

https://www.imf.org/external/pubs/ft/fandd/2001/09/hellman.htm. Accessed: 09 September 2018.

Meirotti, M. and Masterson, G. (2018). State Capture in Africa. Old threats, new packaging? Johannesburg: EISA.

OECD. (2017). Preventing Policy Capture. Integrity in Public Decision Making. Available from: https://dx.doi.org/10.1787/9789264065239-en. Accessed: 09 September 2018.

Republic of Botswana. (2016). Vision 2036 - Achieving Prosperity for All. Gaborone: Letswe La Lesedi (Pty) Ltd.

Transparency International. (2014). State Capture: An Overview. https://www.transparency.org/files/content/corruptionqas/State_capture_an_overview_2014.p df 